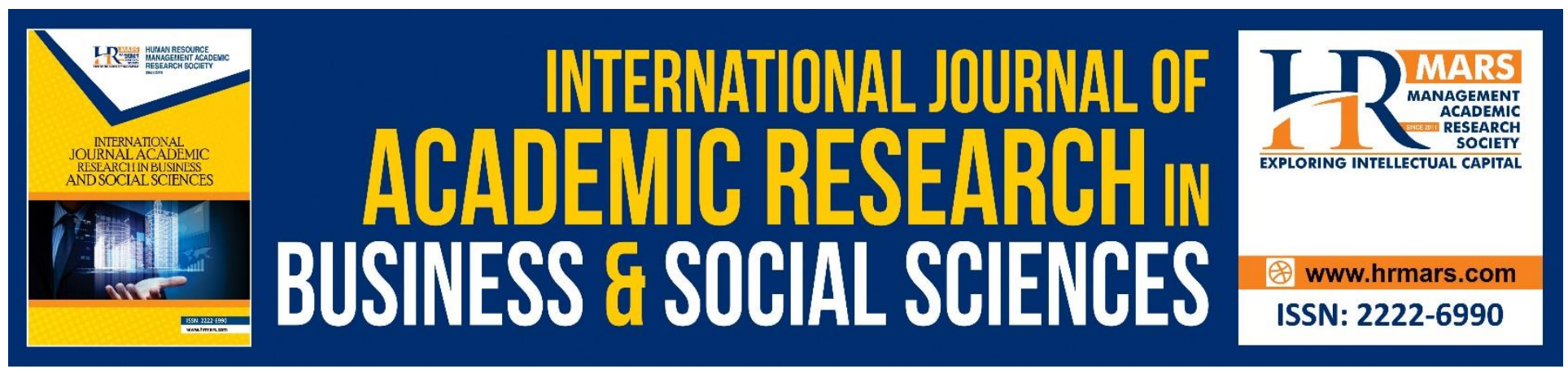

\title{
Antecedent of Employees' Career Satisfaction: An Empirical Investigation of Pharmaceutical Sector of Pakistan
}

Muhammad Naseer, Ayaz ul Haq, Muhammad Farooq

To Link this Article: http://dx.doi.org/10.6007/IJARBSS/v8-i7/4341

DOI: $\quad 10.6007 /$ IJARBSS/v8-i7/4341

Received: 06 June 2018, Revised: 23 June 2018, Accepted: 23 July 2018

Published Online: 29 July 2018

In-Text Citation: (Naseer, Haq, \& Farooq, 2018)

To Cite this Article: Naseer, M., Haq, A. ul, \& Farooq, M. (2018). Antecedent of Employees' Career Satisfaction: An Empirical Investigation of Pharmaceutical Sector of Pakistan. International Journal of Academic Research in Business and Social Sciences, 8(7), 281-299.

Copyright: (C) 2018 The Author(s)

Published by Human Resource Management Academic Research Society (www.hrmars.com)

This article is published under the Creative Commons Attribution (CC BY 4.0) license. Anyone may reproduce, distribute, translate and create derivative works of this article (for both commercial and non-commercial purposes), subject to full attribution to the original publication and authors. The full terms of this license may be seen

at: http://creativecommons.org/licences/by/4.0/legalcode

Vol. 8, No. 7, July 2018, Pg. 281 - 299

http://hrmars.com/index.php/pages/detail/IJARBSS

JOURNAL HOMEPAGE

Full Terms \& Conditions of access and use can be found at http://hrmars.com/index.php/pages/detail/publication-ethics 


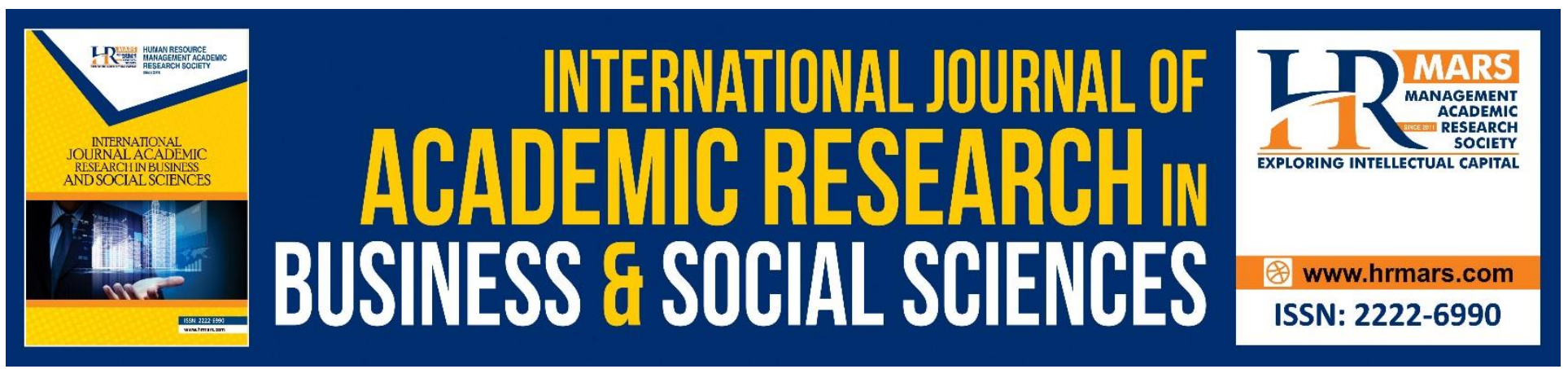

\title{
Antecedent of Employees' Career Satisfaction: An Empirical Investigation of Pharmaceutical Sector of Pakistan
}

\author{
${ }^{1}$ Muhammad Naseer, ${ }^{2}$ Ayaz ul Haq, ${ }^{3}$ Muhammad Farooq \\ 1,3 Limkokwing University of Creative Technology, Cyberjaya, Malaysia \\ ${ }^{2}$ University of Central Punjab, Rawalpindi Campus
}

\section{Abstract}

The study is conducted to determine the significant relationships among Job Satisfaction, Organizational Commitment, Supervisor's Support, and Employee Career Satisfaction. The data have collected from the employees of ten major pharmaceutical companies in Pakistan. Pharmaceutical sector of Pakistan is growing day by day even in law and order situation and energy crisis in country. But high turnover is also reported. This study is conducted to check employee career satisfaction within company and industry. The instrument to measure the variables was adopted from different relevant studies and data was collected from 155 respondents. The SPSS was run on the collected data and analyzed the results. The current study finds a positive correlation between job satisfaction and employee career satisfaction; organizational commitment and employee career satisfaction; and supervisor's support and employee career satisfaction. The main reason to conduct research on the proposed construct is to fulfill the gap and to provide theoretical as well as empirical evidences for researchers, practitioners, and marketers (specially belonging to pharmaceutical organizations). In the real practice, this research is helpful to companies as well as employees of the pharmaceutical industries to understand the behavior of their attitudes towards their profession and the field.

Keywords: Job Satisfaction (JS), Organizational Commitment (OC), Supervisor's Support (SS), and Career Satisfaction (CS).

\section{Introduction \& Background}

As a profound saying is "World has become a Global Village"; this globalization has transformed the landscape of markets and thrust organizations to strategically devise policies about retaining employees as only by doing so ultimate goals and objectives can be successfully achieved. Hence, leveraging employees is the only way of survival for companies in the longer run. Nevertheless, employee management and retention are one of the critical matters to be pondered upon. Studies have provided evidences that organizational sustainability widely dependent on the human capital. For organizations, to train and retain employees for a longer time span totally depends on 
INTERNATIONAL JOURNAL OF ACADEMIC RESEARCH IN BUSINESS AND SOCIAL SCIENCES

Vol. 8, No. 7, July 2018, E-ISSN: 2222-6990 @ 2018 HRMARS

organizational policies, structure, culture, shared policies, and organizational values. Whereas, employee retention is subject to employee satisfaction with his/her job and his/her career.

Therefore, employee career satisfaction is at the heart of this replica.

For a long time, it has been explored on the life and outcomes of organizational accountability (Meyer \& Allen, 1997; Spector, 1997). A lot of researches have been done on this which posits lots of worries that changes in associations make it less possible to maintain responsibility by offering the accepted vocation headway and different affectations that may empower gifted representatives to stay with any company (Adams, 1965; Adeyemo, 2000; Spector, 2006). Furthermore, employees are taking control of their own career and are thinking about boundary less occupation (Ajzen, 1988; DeCotiis \& Summers, 1987).

Most of the researchers believed that the satisfaction and commitment level in the employees is directly related to each other but few of them also considered the employees' point of view to enhance the study for the specific sector (Aronson et. al., 2003; Avery, 1998; Adeyinka, 2007; Ashkanasay, 2010). We know that, the employees are the core human capital in any industry, so their commitment and satisfaction towards firm as well as for them have very important impact on the short and long-term performance of firms, ultimately results in enhanced corporate image. The role of supervisor for any service organization is most important and the role of their employees also becomes a major factor when he/she is dealing with their colleagues. In this situation, the support provided by supervisor becomes very important because if employees are encouraged on the achievement of new skills and abilities then the attitude of employees will be more positive towards the organization as well as with customers. The employee's attitude is considered as most important in any organization for their efficient activities delivered to their supervisors.

This study represents the relationship of support by supervisor towards their employees to boost up their activities and skills for the achievement of best employee's attitudes towards the organization. The employee's attitude towards the organization is very dominant and important because the performance of activities in business is totally dependent on the employees. The role of supervisor for the employees will study in this research.

According to a report published in January 2015,7 developing countries are the driving force for the growth of health and wellness sectors and are forecasted to account for $49 \%$ of the market share by 2019. (Maya Tannoury, 2017). Pharmaceutical sector is industry in Pakistan contributing in major portion of GDP (Gross Domestic Product). Despite of being a very successive industry in Pakistan; unfortunately it is facing a high employee turnover due to the following reasons such as lack of supervisor's support and leadership (sajjad, 2013). Ultimately, it becomes the basis of employee dissatisfaction and lower commitment towards organizational goals and objectives. As a profound saying is "employees don't leave their organization but they leave their bosses". Basically, the abovementioned statement throws a light on the stated construct and puts forwards the notion that lack of supervisor's support, dissatisfaction, and lower employee commitment becomes the basis of lower-employees career satisfaction. In these circumstances, employees mostly, leave their jobs, and seek a better option, which is beyond their perception in the prevailing harsh industry scenario. Thus, 
INTERNATIONAL JOURNAL OF ACADEMIC RESEARCH IN BUSINESS AND SOCIAL SCIENCES Vol. 8, No. 7, July 2018, E-ISSN: 2222-6990 @ 2018 HRMARS

the current study therefore focuses on the importance of a better supervisor's support, jobsatisfaction, and employee commitment on an everlasting and well-committed employees' career satisfaction.

The current study aims to investigate the impact of job satisfaction, organizational commitment, and supervisor's support for increased employee career satisfaction in Pakistani pharmaceutical industry. In addition, the study aims to critically examine the factors that significantly impact these variables so as to get the desired outcomes. Throwing light on pharmaceutical sector in Pakistan, the current paper finds few facts which go in parallel with this study. Initially, pharmaceutical sector in Pakistan is facing severe competition as there are around 800 national and international pharmaceuticals companies operating in Pakistan. Secondly, rather than a more technology-oriented economy, Pakistan is more likely considered as a knowledge-based economy. Therefore, there is an exclusive prevalence of the significance of human capital management in order to stay ahead in the competitive pool.

The significance of job satisfaction, organizational commitment, and supervisor's support are eminent factors for increased employee career satisfaction, hence contributing substantial fallouts in pharmaceutical sectors in Pakistan. Therefore, all these factors are the key employee career satisfaction enablers and hence are the area of concern for researchers and practitioners to conduct research in Pakistani pharmaceutical sector so that the issue of employee turnover can be handled successfully. There is a need to examine the extent to which employee career satisfaction is cushioned by employee job satisfaction, organizational commitment, and supervisor's support. Thus, the study addresses the concern about the correlation between job satisfaction, organizational commitment, and supervisor's support on increased employee career satisfaction.

As mentioned above the significance of human capital on organizational performance, and on the other hand, the importance of pharmaceutical industry for overall economic development of the country; the study lays the foundation of a sound theoretical framework which not only has identified the gap which has become a harsh reality now days, but also created the link, of these variables on the fast-leading industry of Pakistan. Pharmaceutical industry is supposed to be the largest job offering sector in Pakistan, but due to the toughest competition which has arisen due to lots of competitors, the focus has shifted from a well-recognized cause to the ruthless competition.

Around 700 multi-nationals and national's pharmaceutical corporations are working in Pakistan. This means each individual product will be having multiple of hundreds of alternatives. Ultimately, if other things remain the same, each product will be having the same probability of being selected and sold. But, the scenario is quite different but not unusual. The organizations are supposed to hire people to just attain their targets. The focus that employees are the key capital for any organization is somewhat compromised on these grounds. In order to stay competitive in the market place, these pharmaceutical organizations have become self-centred. Even, employee's own goals and objectives are being compromised in order to achieve organizational goals and objectives. The reason behind that is lack of a proper leadership and supervisor's support.

The objectives of the Study are 
INTERNATIONAL JOURNAL OF ACADEMIC RESEARCH IN BUSINESS AND SOCIAL SCIENCES Vol. 8, No. 7, July 2018, E-ISSN: 2222-6990 @ 2018 HRMARS

- To examine the impact of job satisfaction on employee career satisfaction.

- To examine the impact of organizational commitment on employee career satisfaction.

- To examine the influence of supervisor's support on employee career satisfaction.

\section{Literature Review}

\section{Job Satisfaction}

The phenomena of job satisfaction and dissatisfaction is explained by Locke (1969) that job satisfaction is an emotional state of individual's job attaining or facilitating his/her job's values, and the job dissatisfaction is the negative emotional state in which one's job is too frustrating or blocking the attainment of other job's values.

The theory of job satisfaction by Herzberg et al., describes that the employees have two kinds of needs in general prospect: (i) Hygiene, and (ii) Motivation. The factor of hygiene is dependent on supervision, physical working conditions, interpersonal relations and affairs, salary and other compensatory benefits, etc (Herzberg, 1964). According to Vroom (1967:99), job satisfaction is the response of an employee that how much he is satisfied with his current job that he is performing. It is also the feedback of an employee against the role they play in their offices. Blum and Naylor (1986) describe job satisfaction as a common and general behaviour of a worker with his peers and shows his commitment with his tasks and few other conditions such as the degree of their happiness with their wages, job hours, working conditions, social relations, appreciation of skills/talent, individual characteristics, and team relations other than office or work area.

In a nutshell, job satisfaction is the sum of the emotions associated with the job conducted. If the employee thinks that the things that he is performing in the office is appreciable so that would be a positive thing for the worker and if he is trying his best in office but have no comments from his seniors and no appreciation from his group members so that would be a negative thing for an employee (Bittel \& Ramsey, 1983; Blau \& Boal, 1989; Lawler, 1981). With the help of all these definitions, we can describe the job satisfaction as the totality of all negative and positive features related to one's remuneration, his physical working conditions (Carr, 2001; Lowe et. al., 1996), the level of success (Blum \& Naylor, 1986; Likert, 1967), rewards awarded for these achievements, the status maintained due to this job, relationships with his juniors, peers and seniors. Only a single factor does not cause result as in causing satisfaction or dissatisfaction (Brief, 1998). Job satisfaction outcome can be obtained if all these factors exist. Above-mentioned construct leads the basis and provides justifications about job satisfaction of employees with respect to their career commitment. Those organizations which have lower rate of job satisfaction have to face the alarming situations. Employees working in Stressful conditions and unsupportive organizational environment had less desire to stay with the organization as compare to organizations with supportive organizational environment (Louis Tze-Ngai Vong et all, 2018). In order to maintain a healthy environment in an organization job satisfaction level of employees should be increased. With the help of healthy environment in a company the company can achieve good job satisfaction parameter. It was studied conducted in banking sector that when employee ages, employee job satisfaction shows positive trend. When employee become older, his spiritualism and dedication to work and duty increases, and his chances to switch becomes lesser. With compare to younger employees, they have energy, expectations and have more choices and less job satisfaction (Kamal and Sengupta, 2008, 2009). Study conducted on job and career satisfaction concluded that people having job with unrealistic goals have higher turnover and more dissatisfied. It also explained that employee with realistic goals and performance are more satisfied and successful in their careers (Zaidi \& lqbal, 2011). 
INTERNATIONAL JOURNAL OF ACADEMIC RESEARCH IN BUSINESS AND SOCIAL SCIENCES Vol. 8, No. 7, July 2018, E-ISSN: 2222-6990 @ 2018 HRMARS

Employee Job satisfaction is "pleasant and motivating emotional condition which results from the evaluation of employee's job (Locke 1976, p. 1300). Job satisfaction measurement ranges from overall Job Satisfaction Scale (Goyder, 1986) to multiple measures of diverse aspects of job satisfaction. These are also present in Hall and Moss (1998) Job Descriptive Index (JDI). An earlier examination of the OP-job satisfaction relationship is mostly found a contrary relationship. In this study, five-item of scale is being selected to measure employee job satisfaction.

\section{Organizational Commitment}

Employees having strong commitment to their organizations have strong dedications to the organizational objectives and goals to stay in the organization for long term (Smith et. al., 1983). There are many reasons due to which individuals may become committed to an organization: employee will not quit his organization because his firm's values, mission, and goals are equivalent to his own; and one another employee will continue his job because if he/she quits it may hamper his respect, benefit, or networks; and another who sticks to the company because of his sense of obligation. The three types of commitments -affective, continuance, and normative are independent commitment types and binding experience at different levels by all individual employees of company (Meyer \& Allen, 1997).

Mental contracts assistance expedites the trade handle as they produce distinctive suspicions of one's incitements and commitments (Sosdian \& Sharp, 1980). This persistent proportional cycle upgrades an individual's association with the organization (Meyer, 1997), and enhances employee's organizational and his own objectives achievement ambitions (Stewart, 1994). Moreover, contract break is accountable to reduce levels of trust in the professional relationship and distinguishing proof with the association heading people to put their investment after those of the association (Millward \& Hopkins, 1998). Furthermore, continuation duty is liable to expand or remain unaltered while full of feeling responsibility is liable to lessening and emulating breaks (Misener et. al., 1996). In an earlier research, employee organizational commitments were being measured in 27-item scale. In this 27item scale 24 items for employee commitment were being developed in 1990 by Allen and Meyer. And remaining three items for employee commitment is being taken by Irving, et. al., (1997), basically developed it for knowing reasoning that why employee leave any organization? In 1990, Meyer said that this model which is developed to measure an employee organization commitment is valid and reliable because it includes all necessary items for measuring.

It has been observed that employee career satisfaction, organizational commitment, and employee turnover intentions are frequently used to measure job performance and satisfaction constructs. Moreover, studies have been found relationship among employee career satisfaction, organizational commitment and employee turnover intentions (Lambert et al., 2001; Shields and Ward, 2001). Studies are also found discussing relationship among job satisfaction, organizational commitment and career satisfaction (Wang, 2005; Xie, 2005).

\section{Supervisor Support}

Supervisor or leader or manager plays a very important role in any organizational work place. The role of supervisor is to directly communicate with his employees and solve their problems relating to work as well as to gather their feedback for performance appraisal. Mobley et. al., (1978) said that supervisor's attitude and behaviour with his employee or follower at work place highly affects their performance. Moore and Holbrook (1990) said about supervisor of any organization that when team 
INTERNATIONAL JOURNAL OF ACADEMIC RESEARCH IN BUSINESS AND SOCIAL SCIENCES Vol. 8, No. 7, July 2018, E-ISSN: 2222-6990 @ 2018 HRMARS

work is being introduced, the role of any supervisor in any organization is being more significant. Furthermore, Keenan and Newton (1986) conducted study on it and identified different options in supervisor which does not give much emphasis of supervisor in team work. Employees ' perception towards work can enhance their job satisfaction through supervisor support, Qureshi, Muhammad Asif \& Hamid, Kamal. (2017).

A lot of studies have been conducted by Gannon et. al., (1971); Hallock et. al., (2004); Goyder (1986) and they all advocated about leadership in organization that importance of leadership in any organization cannot be negligent when organization is at initiation stage of team promoting or ongoing team promoting at work place but it should be considered very important variable in the model of employee job satisfaction.

Supervisor's most important role is to act as a liaison between subordinates and top-management. Employees of any organization are key elements which are playing very important role in the progress and best performance of any organization. So, their behaviour and attitude at work place is being observed because these are very important factors which are affecting overall organizational performance. So, attitudes of employee in organization are being measured in different dimensions such as:

Supervisors/managers may do more in employee retention management than as recommended in research literature. Important managerial job descriptions contain his individual concern, career guidance, giving importance to employee input, and successes celebrations with employees (Thyer, 2003). Employee can lead his career successfully with the help and guidance of his immediate supervisor. Supervisor/manager support is an important segment in employee career towards his and organizational productivity.

Employees can get better their career success through setting their long- and short-term goals, by enhancing their competencies, and through discussing their career plan with their managers. Turnover can be reduced through better managerial support \& training, managers should hold responsible for retention, career management and HR systems should better through increasing more non-monetary rewards, and also knowing reasons from those employees who have left (Ilies \& Judg, 2003).

Supervisory-support environment has some significance on Employee retention. Through social exchange theory point of view, when employees feel that their supervisors/managers are giving support and concern for their welfare and career, they may feel their emotional binding with manager and organization and in this return, it would lead to employee retention in the organization (Hespanol et. al., 1999). Managers are perceived as representatives of any organization therefore their role is important in the organization. Managers play an important role in shaping attitude and behaviour and their commitment level towards the organization. Managers/supervisors also play a role of mentor as well therefore subordinates follow them in their official career usually and sometime in their practical life. A good manager/supervisor leads his team to career and organizational success and commitment. To raise the organizational commitment in employees the compensation and supervisory support play significant role, these two are important variables as result shows are increasing commitment level in pharmaceutical industry (Ilies \& Judg, 2003).

Supervisor support is an important variable and good manager support leads to longer employee retention within the organization. Employees develop and maintain higher levels of motivation to learn and ensuring a sound support from the peers and supervisors (Ilies \& Judg, 2003). It is observed usually employees don't leave the organizations but they leave their managers. An experienced employee some time switches other organization due to bad attitude of his immediate manager and 
INTERNATIONAL JOURNAL OF ACADEMIC RESEARCH IN BUSINESS AND SOCIAL SCIENCES Vol. 8, No. 7, July 2018, E-ISSN: 2222-6990 @ 2018 HRMARS

sometime due to his good attitude he left and joins new organization where his boss has switched. Furthermore, the results give facts in support of managerial involvement to enhance control and, ultimately, reducing the negative outcomes of a lack of organizational support on employees' organizational commitment (Irving et. al., 1997). Here in this study author analyzes the impact of supervisor support upon employee retention and longer stay within the organization. (Buzdar, Janjua, and Khurshid 2016; Farooq et al. 2018; Farooq and Jabbar 2014; Qadir and Farooq 2018)

Manager or supervisor support is an import factor which leads and effect to employee career satisfaction (Greenhouse, Parasuraman and Wormley, 1990; Cox and Nkomo, 1991; Igbaria and Wormley, 1992; Schneer and Reitman, 1994). Particularly, the top-level management' has been found to be positively related with higher employee career satisfaction (Martins, Eddleston and Veiga, 2002) and receiving 'challenging and visible jobs' was found to positively correlate with career satisfaction (Richardsen, Michelsen and Burke, 1997). August and Waltman (2004) and Auster and Ekstein (2001) also identified the relationship between employees' perceptions of equity and career satisfaction. Employees' perceptions of skill utilization and education/training utilization should also be explored since employers are reportedly under-utilizing immigrant employees' skills (Reitz, 2001, 2007), despite findings that employees' perceptions of skill utilization associates with their career satisfaction levels (Aryeel, 1993). Finally, commitment is important to examine due to its positive effect on career satisfaction (Hochwarter et al., 2004; Poon, 2004; Cox and Nkomo, 1991) and its significant, negative correlation with turnover intention (Cunningham and Sagas, 2007).

\section{Career Satisfaction}

Career satisfaction with regarding to career research, and employee career satisfaction are used in this study. Companies are trying to earn more and more profit. This kind of profit can be maximized through employees' productivity. Productivity of a worker depends upon his job satisfaction level. Job satisfaction has few steps. First company provides him a skilled manager who trains him to right way. Secondly employee has good coordination with his immediate boss. Coordination with boss plays important role in job satisfaction and performance. Along with strong communication there is need of strong coordination among manager and employees for better productivity. Manager or supervisor is the only key person who clearly defines company's goals and objectives to his subordinates and guides them to the right way which fulfils organizational targets, goals and objectives.

The job satisfaction of human resources with company environment is a good sign of better performance. Environment has direct effect on employees' productivity and job satisfaction. Satisfaction with career enhances organizational productivity. It enhances the efficiency, productivity and organizational commitment. It also increases cohesiveness and bindings of co-workers. On the other hand, it reduces negative outcomes. It minimizes the employee turnover rate and unexpected behaviour at work place. It reduces the absenteeism and shoplifting of company property. Job satisfaction has also direct concern with organizational commitment (Thyer, 2003). Job satisfaction topic is concerned with employees, employer and to those who study this important issue (Ironson et. al., 1989).

Job satisfaction variable is very important both for employee and employer as well for better productivity. It shows that satisfied worker shows more loyalty to its organization and therefore is less likely to change its job and will work hard and with determination for the organizational productivity (Sinen, 2010). This leads to less turnover and longer employee stay within the 
INTERNATIONAL JOURNAL OF ACADEMIC RESEARCH IN BUSINESS AND SOCIAL SCIENCES Vol. 8, No. 7, July 2018, E-ISSN: 2222-6990 @ 2018 HRMARS

organization. This variable is most studied by researchers and also has its importance. In this study job satisfaction is taken as independent variable and its direct impact will be observed at employee career satisfaction. Employee always feel motivated and satisfied with their career when they perceive that their organization is supportive and when there is a perception that the organization thinks about wellbeing of employees. The study found significant influence of Perceived Organizational support on employee career satisfaction. Employees work hard when there is thinking that the Organization is rewarding them according to the work they perform (Latif, 2013, Belinda2007).

Therefore, this finding suggests that organizational Support for career development initiatives that promote the individual benefits associated with career management behaviors and encourage employees to engage in these behaviors, may experience most success in facilitating employee career satisfaction (Karen et. al., 1999; Organ \& Konovsky, 1989; Peters et. al., 1981). Wang, J., Tsai, K., Lei, L., Chio, I., \& Lai, S. (2016) found that employees' organizational commitment and jobsatisfaction can predict their turnover intention. Career satisfaction is defined as positive work-related upshot or achievements that a person or employee accumulates as a result of work experiences (Judge et al., 1995). Models of career satisfaction have included a number of demographic, human capital, and motivational variables related to career success (Judge and Bretz, 1994; Judge et al.,1995). In the past, much research on careers has viewed the individual as being passive and influenced by situational factors (Bell and Staw, 1989). However, more recent studies have assumed that personality through certain behaviours can have a direct effect on the environment. Some researchers have found this with respect to studying career satisfaction (Seibert et al., 1999). Thus, we examined the role of job satisfaction, organizational commitment and supervisor support on career satisfaction in this study.

\section{Hypotheses Statement}

H1. Job Satisfaction has positive relationship with Career Satisfaction.

H2. Organizational Commitment has positive relationship with Career Satisfaction.

H3. Supervisor's Support has positive relationship with Career Satisfaction.

\section{Research Methodology}

This part of study demonstrates the methodology that the researcher has adopted to undertake the investigation on multiple factors like job satisfaction, organizational commitment, supervisor support and employee career satisfaction. Pilot testing, sample size, time horizon, measuring scale is discussed in detail.

Current research is applied research and by using quantitative approach, the responses from the group of people (population) gathered. This approach used in behavioral studies (social sciences, sociology, etc.). The current study is applied research in nature because hypothetical statements tested in order to determine the significance level among the predictors and dependent variable of proposed model. This study used Hypotheticaldeductive approach (Sekaran, 2000);

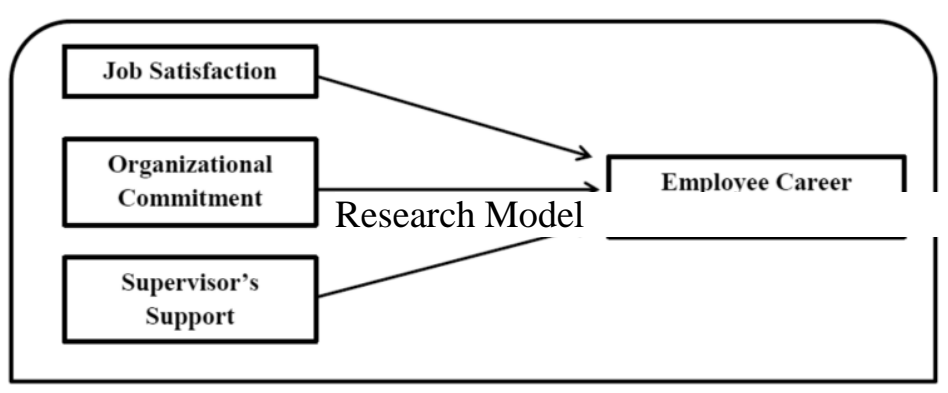


INTERNATIONAL JOURNAL OF ACADEMIC RESEARCH IN BUSINESS AND SOCIAL SCIENCES Vol. 8, No. 7, July 2018, E-ISSN: 2222-6990 @ 2018 HRMARS

Questionnaires were distributed among Pharmaceutical professionals for preliminary data collection and to get the clear vision regarding problem definition. Literature review provides clear instructions to approach the same problem in different contexts. Such studies review performs essential role in selection of study measure. In-depth literature review provides clearer and complete conceptualization of research variables. Without complete understanding of research problem and literature, it was not possible to build hypotheses and validation of proposed hypotheses in the study. Data collection was conducted by designing questionnaire in familiar language (English) and aimed at the employees of the pharmaceutical industry to empirically test the proposed hypotheses. Researcher collects one-time data from employees to determine their perception regarding organizational performance factors. Therefore, the design of current study was cross-sectional.

Subject to items ratios was the important rule considered to determine the sample size for study (Edward \& Wayne, 1998). Sample size was calculated based on number of observations per variables that is $20: 1$ or $50: 1$ is important statistically mechanism to determine the sample size (Osborne \& Costello, 2004). Based on above evidences, current study has four predictor observations, based on subject to items ratios 200, and was determined as sample size for this study. The variables of this study are Job Satisfaction (JS), Organizational Commitment (OC), Supervisor's Support (SS), and Career Satisfaction (CS) in which Job Satisfaction (JS), Organizational Commitment (OC), and Supervisor's Support (SS) are independent variables and Career Satisfaction (CS) is dependent variable. The five - point Likert Scale ( 1 = Strongly Agree, $2=$ Agree, 3= Not Agree, Nor Disagree, $4=$ Disagree, 5 = Strongly Disagree) is used to measure the variables (job satisfaction, organizational commitment, supervisor's support, and career satisfaction).

The target population was currently working employees in different pharmaceutical industries all around the Pakistan. To collect the data from respondents, we use convenience approach in which random respondents select and fill the questionnaires from them by their own will. The random selection of respondents is very helpful when we analyze the results because the factor of biasness remains no more dominant in it. We distributed 180 questionnaires in the target audience on the Paper \& Pencil. The exchange rate of return was about $86.11 \%$ from which 155 were bias free. All other questionnaires were not valid for the data analysis.

For the scale of Job Satisfaction (JS), researcher used the instrument of Spector (1997) from the study of "Job Satisfaction, Application, Assessment, Causes, and Consequences". This instrument was based on five questions with the scale of five - point Likert scale. The overall reliability of this measuring scale is 0.0807. For the scale of Organization Commitment (OC), we used the instrument of Allen and Meyer (1990) from the study of "The Measurement and Antecedents of Affective, Continuous, and Normative Commitment to the Organization". This instrument was based on thirty questions anchored by Strongly Disagree to Strongly Agree. The overall reliability for this measuring scale is 0.803.

For the Supervisor Support (SS), instrument of adopted the Lowtheom et al., (1997). This instrument was based on five questions and their responses were measured on five Likert Scale anchored by Strongly Agree to Strongly Disagree. The overall reliability (Cronbach's Alpha) of the scale was 0.68. For the Career Satisfaction (CS), instrument of Timothy adopted the instrument of Timothy, Cable, Boudreau, John and Bretz, (1994). This instrument was based on five questions and their responses were measured on five Likert Scale anchored by Strongly Agree to Strongly Disagree. The overall reliability (Cronbach's Alpha) of the scale was 0.85 .

In order to ensure the reliability of the developed instrument, validity and reliability were conducted for pilot testing. Whereas, validity represents the extent to which the measurement scales are a 
INTERNATIONAL JOURNAL OF ACADEMIC RESEARCH IN BUSINESS AND SOCIAL SCIENCES Vol. 8, No. 7, July 2018, E-ISSN: 2222-6990 @ 2018 HRMARS

representative of the target population. For ensuring reliability, Cronbach's Alpha is applied and found reliable. The study is conducted to identify the impact of job satisfaction, organizational commitment, and supervisor's support on employee career satisfaction. The target population for this study is employees working in national and multinational pharmaceutical companies. A total of 180 research questionnaires were personally administered by the researcher while a sum of 155 was received in full with a response rate of $86 \%$. For empirical analysis, SPSS 20.0 was used. Following tests were analyzed based on the research design including, descriptive statistics, correlations analysis and structural equation modelling (SEM) technique using AMOS 18.0.

\section{Results and Discussion}

The target population for this research is employees working in pharmaceutical firms in Pakistan. Pharmaceutical employees working in Islamabad/Rawalpindi and Peshawar were taken as the sample of this study. A total of 180 questionnaires were administered out of which a total of 155 were received in full. This sample includes the sample for pilot study too which was 40 with respect to this study.

TABLE 4.1 Correlations

\begin{tabular}{llllll}
\hline & & JS & OC & SS & ECS \\
\hline JS & Pearson Correlation & 1 & & & \\
OC & Pearson Correlation & $.625^{* *}$ & 1 & & \\
SS & Pearson Correlation & $.660^{* *}$ & $.787^{* *}$ & 1 & \\
ECS & Pearson Correlation & .534 & $.696^{* *}$ & $.657^{* *}$ & 1 \\
\hline
\end{tabular}

**Correlation is significant at the 0.01 level (2-tailed).

Table 4.1 indicates the correlations analysis of this study. The data shows a positive correlation among variables. Furthermore, the value of $P$ (significance) should be less than 0.05 in order to justify the results. Whereas, all values in above table are below than 0.05 which means that results are significant. Results show that organizational commitment highly impacts employee career satisfaction with the correlation of 0.66 with significance of 0.000 , whereas, job satisfaction is at the lowest though positive with 0.534 having significance of 0.000 .

TABLE 4.2 Descriptive Statistics

\begin{tabular}{|c|c|c|c|c|c|c|c|c|c|}
\hline & $\mathrm{N}$ & $\begin{array}{l}\text { Minimu } \\
\mathrm{m}\end{array}$ & $\begin{array}{l}\text { Maximu } \\
\mathrm{m}\end{array}$ & Mean & $\begin{array}{l}\text { Std. } \\
\text { Deviation }\end{array}$ & \multicolumn{2}{|c|}{ Skewness } & \multicolumn{2}{|l|}{ Kurtosis } \\
\hline & $\begin{array}{l}\text { Statisti } \\
\text { C }\end{array}$ & Statistic & Statistic & $\begin{array}{l}\text { Statisti } \\
\text { C }\end{array}$ & Statistic & $\begin{array}{l}\text { Statisti } \\
\text { C }\end{array}$ & $\begin{array}{l}\text { Std. } \\
\text { Error }\end{array}$ & $\begin{array}{l}\text { Statisti } \\
\text { c }\end{array}$ & $\begin{array}{l}\text { Std. } \\
\text { Error }\end{array}$ \\
\hline JS & 155 & 1.60 & 6.00 & 2.1355 & .68941 & 3.451 & .195 & 17.244 & .387 \\
\hline OC & 155 & 1.67 & 4.00 & 2.4151 & .55158 & .591 & .195 & .160 & .387 \\
\hline SS & 155 & 1.00 & 5.00 & 2.2645 & .94661 & 1.550 & .195 & 1.569 & .387 \\
\hline ECS & 155 & 1.40 & 3.40 & 2.0865 & .48885 & 1.057 & .195 & .907 & .387 \\
\hline
\end{tabular}

Table 4.2 indicates the descriptive statistics of the whole sample. In pilot testing, only the data from 40 respondents was processed for this analysis in order to confirm any abnormality in the data. A goahead from previous section becomes the basis for conducting the main study. A total of 155 
INTERNATIONAL JOURNAL OF ACADEMIC RESEARCH IN BUSINESS AND SOCIAL SCIENCES

Vol. 8, No. 7, July 2018, E-ISSN: 2222-6990 @ 2018 HRMARS

respondents returned complete questionnaires. The data again represents the normality of data as per in above table.

Model Testing:

Table 4.3: ANOVA

\begin{tabular}{lllllll}
\hline \hline Model & & $\begin{array}{l}\text { Sum } \\
\text { Squares }\end{array}$ & of Df & Mean Square & F & Sig. \\
\hline \multirow{3}{*}{1} & Regression & 82.936 & 3 & 27.645 & 53.620 & $.000^{\mathrm{b}}$ \\
& Residual & 200.561 & 389 & .516 & & \\
& Total & 283.498 & 392 & & & \\
\hline \hline
\end{tabular}

a. Dependent Variable: ECS

b. Predictors: (Constant), SS, OC, JS

Our results of study show that model is significant. F values are greater for 4 and significant values are less than 0.05. Regression coefficient is a measure of how strongly each IV predicts the DV. Significance of the model "Did the model explain the deviations in the dependent variable (ECS)" the last column (sig) shows the goodness of fit of the model. The lower this number, the better the fit of model is. Typically, if "Sig" is greater than 0.05 , we conclude that our model could not fit the data butt in this study it less than 0.05. The TSS (Total Sum of Squares) is the total deviations in the dependent variable (ECS). The aim of the regression is to explain these deviations (by finding the best Beta that can minimize the sum of the squares of these deviations). The ESS (Explained Sum of Squares) is the amount of the TSS that could be explained by the model.

Table 4.4: Model Summary

\begin{tabular}{|c|c|c|c|c|c|}
\hline Model & $R$ & R Square & $\begin{array}{l}\text { Adjusted } \\
\text { Square }\end{array}$ & $\begin{array}{l}\mathrm{R} \text { Std. Error o } \\
\text { the Estimate }\end{array}$ & $\begin{array}{l}\text { Durbin- } \\
\text { Watson }\end{array}$ \\
\hline 1 & $.541^{\mathrm{a}}$ & .293 & 287 & .71804 & 1.477 \\
\hline
\end{tabular}

a. Predictors: (Constant), SS, OC, JS

b. Dependent Variable: ECS

Adjusted R-square Measures the proportion of the variance in the dependent variable (ECS) that was explained by variations in the independent variables (IS, OC, SS). In this study, the "Adjusted R Square" shows that $28.7 \%$ of the variance was explained. Standard error of the estimate measures the dispersion of the dependent variable (ECS) estimate around its mean (in this study, the "Std. Error of the Estimate" is .718). By comparing this to the mean of the "Predicted" values of the dependent variable, the Std. Error is $78 \%$ of the mean, and it is low. Durbin Watson values are 1.477, which is in range of maximum 4.

Table 4.5: Coefficients

\begin{tabular}{llllll}
\hline \hline Model & \multicolumn{2}{l}{$\begin{array}{l}\text { Unstandardized } \\
\text { Coefficients }\end{array}$} & $\begin{array}{l}\text { Standardized } \\
\text { Coefficients }\end{array}$ & T & Sig. \\
\cline { 2 - 4 } & $\mathrm{B}$ & Std. Error & Beta & & \\
\hline (Constant) & 1.779 & .169 & & 10.499 & .000 \\
\hline \hline
\end{tabular}


INTERNATIONAL JOURNAL OF ACADEMIC RESEARCH IN BUSINESS AND SOCIAL SCIENCES

Vol. 8, No. 7, July 2018, E-ISSN: 2222-6990 @ 2018 HRMARS

\begin{tabular}{llllll}
\hline JS & .271 & .056 & .310 & 4.828 & .000 \\
OC & .229 & .054 & .239 & 4.220 & .001 \\
SS & .321 & .065 & .351 & 5.098 & .000 \\
\hline \hline
\end{tabular}

a. Dependent Variable: ECS

Table 4.33 shows the result, there are three variables which have positive influence on ECS, namely JS, OC and SS ( $B=0.361, p$-value $<0.05)$.

\section{Discussion}

Former section presents analysed data in order to justify the developed constructs. As per this study, job satisfaction, organizational commitment, and supervisor's support positively influence employee career satisfaction. The main reason to conduct this research is to provide a quality research for researchers, academicians, practitioners, and marketers so that the issue of employee turnover can be counterfeiting by executing a well-established as well as developing long-term strategy.

In this respect, extensive formerly conducted studies are cited on job satisfaction, organizational commitment and supervisor's support on employee career satisfaction. Based on the theoretical founding, the current study generated few hypotheses which are empirically tested in Chapter 3 and the results are presented in Chapter 4. Furthermore, the findings of empirical investigation are in harmony with that of the developed theoretical framework. For instance, the study proposed first hypothesis stating $\mathrm{H} 1$ that there is a positive correlation between employee job satisfaction and employee career satisfaction. This hypothesis is well justified in both qualitative and quantitative regards. For example, a research study conducted by Vroom (1967) stated that job satisfaction is the response of an employee that how much he is satisfied with his current job that he is performing, ultimately enhancing his career satisfaction. In another research study by Murawski (2008), he endorsed that job satisfaction is an internal satisfaction of an employee which predicts employee career satisfaction. Seemingly, the results of this study are highly supported and in alliance with the literature review. For instance, the study found a positive influence of job satisfaction on employee career satisfaction with a correlation of 0.534 and regression weight of 0.113 with significance of 0.000 . Though the figure is a little low in percentage yet the study is supported with a positive analysis which supports the first hypothesis.

Extending the discussion section, the study throws light on the qualitative and quantitative synchronization of findings such as organizational commitment has a positive correlation with employee career satisfaction and correlated with employee career satisfaction with a value of 0.696. Likewise, regression weight also indicates a higher value of 0.251 which designates that employee career satisfaction goes up by 0.251 if organizational commitment goes up by 1 . The empirical results lie in parallel with that of the qualitative findings such as a research study of Valentine et. al. (2002) validated that employees having strong commitment to their organizations have strong dedications to the organizational objectives and goals to stay in the organization for long term. In the related stream, Meyer (1997) found a positive association between employee career satisfactions with that of organizational commitment. Therefore, quantitative findings support the second hypothesis which states as $\mathrm{H} 2$ there is a positive correlation between organizational commitment and employee career satisfaction.

The third hypothesis is $\mathrm{H} 3$ which proposes a positive correlation between supervisor's support and employee career satisfaction. The current study generated this hypothesis based on the following studies' findings including: Durham (1997) said that supervisor's attitude and behaviour with his 
INTERNATIONAL JOURNAL OF ACADEMIC RESEARCH IN BUSINESS AND SOCIAL SCIENCES Vol. 8, No. 7, July 2018, E-ISSN: 2222-6990 @ 2018 HRMARS

employee or follower at work place highly affects their performance; Manz and Sim (1987); Vathsala (2010); Bass (1997) and they all advocated about supervisors' support in an organization that importance of leadership in any organization cannot be negligent when organization is at initiation stage of team promoting or ongoing team promoting at work place but it should be considered very important variable in the model of employee job satisfaction. The findings of current study regarding supervisor's support are also in parallel with the literature review e.g. the study found a positive correlation of 0.657 and a regression weight of 0.189 with significance value of less than 0.002 . Both the qualitative and quantitative findings justify the third hypothesis i.e. H3. Thus, the study provides enough evidences theoretically as well as empirically on the positive impact of job satisfaction, organizational commitment, and supervisor's support on the employee career satisfaction.

\section{Conclusion \& Recommendations}

The present study aims to identify the impact of job satisfaction, organizational commitment, and supervisor's support on employee career satisfaction in Pharmaceutical companies in Pakistan. Results provide enough evidences about the significant as well as positive relationships of the abovementioned variables. In lieu of competitive eccentricity, employee career satisfaction is highly compromised by anyone of the factors if not strategically leveraged by organizations. Therefore, it is eminent pharmaceutical companies to take into consideration each aspect in order to yield maximum employee performance. Therefore, the study conducted empirical investigation and finds the positive correlation between job satisfaction and employee career satisfaction; organizational commitment and employee career satisfaction; and supervisor's support and employee career satisfaction. The main reason to conduct research on the proposed construct is to fulfil the gap and to provide theoretical as well as empirical evidences for researchers, practitioners, and marketers (specially belonging to pharmaceutical organizations).

Recent survey on national and multinational companies in pharmaceutical industry reveals that around 800 private pharmaceutical companies are operating in Pakistan. Thus, the industry is facing a fierce competitive environment inside it which has turned into fluctuating rates of turnovers with respect to sales (turnover) and employees (turnover). Therefore, the current study is a contribution in this field, as it is pioneer on this ground as well as it provides sufficient facts by reviewing literature specially conducted in developing countries inclusively Pakistan. Researcher took data from respondents working in this industry and a response rate of $86.1 \%$ has been gotten which is wellenough to generalize the results. Results show positive correlation analysis among variables. Value of $P$ was less than 0.02 to justify the results. Cronbach alpha was found $71.7 \%$ for all variables for this study to ensure reliability of the measurement scale.

Finally, employee career satisfaction has been significantly focused in this study. Researches are available focusing on job satisfaction, but a few studies are found to be identifying the impact of job satisfaction on employee's career satisfaction. Nonetheless the other corporations; the sales department in pharmaceutical organizations has been affected due to job dissatisfaction, lack of leadership, and organizational commitment. This ultimately became the basis of lowering employees' morale about their future career. Thus, employee career satisfaction is an area of concern to be examined both theoretically as well as empirically. In addition, the current study provided much evidence on the importance of employee career satisfaction. The fragility of this dilemma lies with strong interconnections among job satisfaction, organizational commitment, and supervisor's support in order to retain potential employees for long-term in pharmaceutical companies. 
INTERNATIONAL JOURNAL OF ACADEMIC RESEARCH IN BUSINESS AND SOCIAL SCIENCES Vol. 8, No. 7, July 2018, E-ISSN: 2222-6990 @ 2018 HRMARS

In this research work, researcher has found that supervisor support plays an important role in employees' career satisfaction. Therefore, Pharmaceutical companies should consider this factor along with Job satisfaction and Organizational Commitment to overcome increased employee turnover ratio. As far as limitation is concerned, Data have collected from only three cities, female employees are not taken, Sales staff is only considered and study is conducted on only three variables i.e. Job Satisfaction, Supervisor Support and Organizational Commitment to evaluate Employees' Career Satisfaction. Researchers should consider top level management, female workers, Salary/Remuneration, Incentive Policies and Training \& Development factors for future research works.

\section{References}

Adams, J. S. (1965), Inequity in social exchange. In L. Berkowitz (Ed.), Advances in experimental psychology, 2, pp. 267-299. New York: Academic Press.

Adeyemo, D.A. (2000), “Job involvement, career commitment, organizational commitment and job satisfaction of the Nigerian police: A multiple regression analysis", Journal of Advance Studies in Educational Management, 5(6), 35-41.

Ajzen, I. (1988), Attitudes, personality, and behaviour. Chicago: Dorsey Press.

Allen T.D., Eby L.T., Poteet M.L., Lentz E, and Lima L. (2004), “Career benefits associated with mentoring for protégés: A meta-analysis", Journal of Applied Psychology, 89, 127-136.

Aryeel, S. 1993. "Dual-earner Couples in Singapore: An Examination of Work and Nonwork Sources of their Experienced Burnout." Human Relations, 46 (12), 1441-1468.

August, L., and J. Waltman. 2004. "Culture, Climate and Contribution: Career Satisfaction among Female Faculty." Research in Higher Education, 45 (2), 177-192.

Auster, E. R., and K. L. Ekstein. 2001. “Professional Women's Midcareer Satisfaction: Toward an Explanatory Framework." Sex Roles, 44 (11-12), 719-750.

Avery, M, (1998), The Impact of Teachers' Demographic Characteristics on the Level of Job Satisfaction in Secondary Schools in Rivers State: A Case Study of Teachers in Rivers State Secondary Schools. M.Ed. Desertation (Unpublished) Port Harcourt: University of Port Harcourt, Nigeria.

Adeyinka, T.C.A. (2007), Work Motivation, Job Satisfaction, and Organisational Commitment of Library Personnel in Academic and Research Libraries in Oyo State, Nigeria. Library Philosophy and Practice.

Anis. (2011). Impact of organizational commitment on job satisfaction and employee retention in pharmaceutical. African Journal of Business Management.

Ashkanasy, Y.L. (2010), "A multilevel model of affect and organizational commitment". Asia Pacific Journal of Management, 27, 193-213.

Belinda, R.B. (2007), "The impact of organizational support for career development on career satisfaction", Career Development International, 12(7), 617-636.

Buzdar, M. F., S. Y. Janjua, and M. A. Khurshid. 2016. "Customer-Based Brand Equity and Firms' Performance in the Telecom Industry." International Journal of Services and Operations Management 25(3).

Bittel, R. and Ramsey, J. E. (1983), “Hourly Supervisory Development: Where the Rubber meets the Road", Training and Development Journal, 37(3), pp.12-20. 
INTERNATIONAL JOURNAL OF ACADEMIC RESEARCH IN BUSINESS AND SOCIAL SCIENCES Vol. 8, No. 7, July 2018, E-ISSN: 2222-6990 @ 2018 HRMARS

Blau, G. and Boal, K. (1989), "Using job involvement and organizational commitment interactively to predict turnover", Journal of Management, 15, pp. 115-127.

Blau, P. M. (1964), Exchange and power in social life. New York: Wiley. Brown, T. R. (1972). A comparison of judgmental policy equations obtained from human judges under natural and contrived conditions. Mathematical Biosciences, 15, 205-230.

Blum, M. and Naylor. J. (1986), Industrial Psychology: Its Theoretical and Social Foundation. New York: Harper and Row.

Brief, A. P. (1998), Attitudes in and around organizations. Thousand Oaks, CA: Sage.

Carr, S. (2001), "As distance comes of age, the challenge is keeping the students", Chronicle of higher education.

Cunningham, G. B., and M. Sagas. 2007. "Examining Potential Differences between Men and Women in the Impact of Treatment Discrimination." Journal of Applied Social Psychology, 37 (12), 3010-3024. DeCotiis, T. And Summers, T. (1987), "A path analysis of a model of the antecedents and consequences of organizational commitment", Human Relations, 40(7), pp. 445-70.

Durham, C.C., Knight, D., and Locke, E.A. (1997), "Effects of leader role, team-set goal difficulty, efficacy, and tactics on team effectiveness", Organizational Behavior and Human Decision Processes, 72, pp. 203-231.

Edwards, J. E. (1997), How to conduct organizational surveys. Thousand Oaks, CA: Sage.

Gannon, M., Nothern, J., and Carroll, S. (1971), "Characteristics of nonrespondents among workers", Journal of Applied Psychology, 55, pp. 586-588.

Goyder, J. (1986), "Surveys on surveys: Limitations and potentials", Public Opinion Quarterly, 50, pp. 27-41.

Greenhouse, J. H., S. Parasuraman and W. M. Wormley. 1990. "Effects of Race on Organizational Experiences, Job Performance Evaluations and Career Outcomes." Academy of Management Journal, 33 (1), 64-86.

Hallock, D.E., Salazar, R.J. and Vennemanw, S. (2004), "Demographic and attitudinal correlates of employee satisfaction with an ESOP", British Journal of Management, 15, pp. 321-333.

Herzberg, F. (1964), "The Motivation-Hygiene Concept and Problems of Manpower", Personnel Administrator (27), pp. 3-7.

Hespanhol, A., Pereira, A.C. and Pinto, A.S. (1999), "Job satisfaction in Portuguese physicians in general medicine", AtenPrimaria, 24, pp. 456-61.

Hochwarter, W. A., C. Kiewitz, M. J. Gundlach and J. Stoner. 2004. "The Impact of Vocational and Social Efficacy on Job Performance and Career Satisfaction." Journal of Leadership and Organizational Studies, 10 (4), 27-40

Ilies, R. and Judg, T.A. (2003), "On the heritability of job satisfaction: the mediating role of personality", Journal of Applied Psychology, 88(4), pp. 750-9.

Ironson, G. H., Smith, P. C., Brannick, M. T., Gibson, W. M., and Paul, K. B. (1989), "Construction of a Job in General Scale: A comparison of global, composite, and specific measures", Journal of Applied Psychology, 74, pp. 193-200.

Irving, P.G., Coleman, D.F., and Cooper, C.L. (1997), "Further assessment of a three-component model of occupational commitment: Generalizability and differences across occupations", Journal of Applied Psychology, 82, pp. 444-452.

Irving, G.P. and Meyer, J.P. (1994), "Reexamination of the met-expectations hypothesis: A longitudinal analysis", Journal of Applied Psychology, 79, pp. 937-949.

Kamal R, Sengupta D (2008-09). A Study of Job Satisfaction of Bank Officers. Pune: NIBM 
INTERNATIONAL JOURNAL OF ACADEMIC RESEARCH IN BUSINESS AND SOCIAL SCIENCES

Vol. 8, No. 7, July 2018, E-ISSN: 2222-6990 @ 2018 HRMARS

Karen, A.J., Gregory, B.N., and Margaret A.N. (1999), Administrative Science Quarterly, 44(4). pp. 741763.

Keenan, T. and Newton, T.J. (1986), "Work aspirations and experiences of young graduate engineers", Journal of Management Studies, 23, pp. 224-37.

Khan, A. S. (2011), "Investigating the demographic impacts on the job satisfaction of district officers in the province of kpk, Pakistan", International Research Journal of Management and Business Studies.

Lambert, E.G., Hogana, N.L. and Bartona, S.M. (2001), "The impact of job satisfaction on turnover intent: a test of a structural measurement model using a national sample of workers", The Social Science Journal, Vol. 38 No. 2, pp. 233-50.

Latif, K.I. (2013), "Perceived Organizational Support, Pay Satisfaction, and Supervisor Satisfaction Impact on Career Satisfaction", Abasyn Journal of Social Sciences, 15(3), 1109-1123.

Lawler, E.E. (1971), Pay and organizational effectiveness: A psychological viewpoint. New York: McGraw-Hill.

Lawler, E.E. (1981), Pay and organizational development. Reading, MA: Addison-Wesley.

Likert, R.L. (1967), New Patterns of Management, McGraw-Hill Book Company, New York, NY.

Louis Tze-Ngai Vong, Henrique Fátima Boyol Ngan, Patrick Chun-Pong Lo, (2018) "Does organizational climate moderate the relationship between job stress and intent to stay?: Evidence from Macau SAR, China", Journal of Chinese Human Resource Management.

Lowe, K.B., Kroeck, K.G. and Sivasubramaniam, N. (1996), "Effectiveness correlates of transformational and transactional leadership: a meta-analytic review", The Leadership Quarterly, 7, pp. 385-425.

Martins, L. L., K. A. Eddleston and J. F. Veiga. 2002. "Moderators of the Relationship between WorkFamily Conflict and Career Satisfaction." Academy of Management Journal, 45 (2), 399-409.

Maya Tannoury, B. Z. (2017). The Influence of Emerging Markets on the Pharmaceutical Industry. Current Therapeutic Research, 19-22.

Meganck, A. D. (2007), "What HR managers do versus what employees value", HR and Organizational Behavior, 38(1), 45-60.

Meyer, J.P. and Allen, N.J. (1991), “A three-component conceptualization of organizational commitment", Human Resource Management Review, 1, pp. 61-98.

Meyer, J. P., and Allen, N.J. (1997), Commitment in the workplace. Thousand Oaks, CA: Sage. Copyright $O 1997$ by Sage Publications, Inc.

Meyer, J.P., Allen, N.J. and Smith, C.A. (1993), “Commitment to organizations and occupations: extension and test of a three-component conceptualization", Journal of Applied Psychology, 78, pp. 538-51.

Millward, L.J. and Hopkins, L.J. (1998), "Psychological contracts, organizational and job commitment", Journal of Applied Social Psychology, 28, pp. 1530-1556.

Misener, T.R., Haddock, K.S., Gleaton, J.U. and Ajamieh, A.R. (1996), "Toward an international measure of job satisfaction", Nursing Research, 45, pp. 87-91.

Mobley, W. H., Horner, S. O., \& Hollingsworth, A. T. (1978), "An evaluation of precursors of hospital employee turnover", Journal of Applied Psychology, 62, pp. 237-240.

Moore, W.L. and Holbrook, M.B. (1990), "Conjoint analysis on objects with environmentally correlated attributes: The questionable importance of representative design", Journal of Consumer Research, 16, pp. 490-497. 
INTERNATIONAL JOURNAL OF ACADEMIC RESEARCH IN BUSINESS AND SOCIAL SCIENCES Vol. 8, No. 7, July 2018, E-ISSN: 2222-6990 @ 2018 HRMARS

Organ, D. W. and Konovsky, M. (1989), "Cognitive versus affective determinants of organizational citizenship behaviour", Journal of Applied Psychology, 74, pp. 157-164.

Peters, L. H., Bhagat, R. S., and O'Connor,E, J. (1981), "An Examination of the independent and a contributions of organizational commitment and job commitment on employee intentions to quit", Group and Organization Studies, 6, pp. 73-82.

Reitz, J. G. 2001. "Immigrant Skill Utilization in the Canadian Labour Market: Implications of Human Capital Research." Journal of International Migration and Integration, 2 (3), 347-378. Reitz, J. G. 2007. "Immigrant Employment Success in Canada, Part II: Understanding the Decline." Journal of International Migration and Integration, 8 (1), 37-62.

Richardsen, A. M., A. Mikkelsen and R. J. Burke. 1997. "Work Experiences and Career and Job Satisfaction among Professional and Managerial Women in Norway." Scandinavian Journal of Management, 13 (2), 209-218.

Sajjad, Zekeriya (2013,March). Arising employees' retention due to organizational commitment \& support in pharmaceutical industry. Elixir International Journal, pp-13407-12

Sinan, C. P. (2010), "Key organizational commitment antecedents for nurses,paramedical professionals and non-clinical staff", Journal of Health Organization and Management, 25(1), 7-33.

Smith, W. G. (2011), "Manager support predicts turnover of professionals in India", Career Development International, 16(3), 293-312.

Skansi, D. (2000), "Relation of managerial efficiency and leadership styles - empirical study in Hrvatskaelektroprivreda", Management, 52, pp. 51-67.

Smith, C. A., Organ, D. W., and Near, J. P. (1983), "Organizational citizenship behaviour: Its nature and antecedents", Journal of Applied Psychology, 68, pp. 653-663.

Smith, P., Kendall, D., and Hulin, C. (1969), The measurement of satisfaction in work and retirement. Chicago: Rand McNally.

Sosdian, C. P. and Sharp, L. M. (1980), "Nonresponse in mail surveys: Access failure or respondent resistance", Public Opinion Quarterly, 44, pp. 396-402.

Spector, P.E. (1997), Job Satisfaction: Application, Assessment, Causes, and Consequences, Sage, Thousand Oaks, CA.

Qadir, A. and Farooq, M. (2018). "Impact of Evaluation Apprehension on Knowledge Sharing Intention through Attitude and Perceived Behavioural Control." International Journal of Academic Research in Business and Social Sciences 8(6):795-811.

Spector, P.E. (2006), "Method variance in organizational research: truth or urban legend?", Organizational Research Methods, 9, pp. 221-32.

Stewart, D.M. (1994), Handbook of Management Skills, 2nd ed., Gower Publishing Co., Aldershot. Stordeur, S., Vandenberghe, C. and D'hoore, W. (2000), "Leadership styles across hierarchical levels in nursing departments", Nursing Research, Vol. 49 No. 1, pp. 37-43.

Thyer, G. (2003), "Dare to be different: transformational leadership may hold the key to reducing the nursing shortage", Journal of Nursing Management, 11, pp. 73-9.

Vathsala, W. (2010), "Impact of career plateau and supervisory support on career satisfaction. A study in offshore outsourced IT firms in Sri Lanka”, Career Development International, 15(6), 544-561.

Vroom, V. H. (1967), Work and motivation. New York: Wiley.

Wang, J., Tsai, K., Lei, L., Chio, I., \& Lai, S. (2016). Relationships among Job Satisfaction, Organizational Commitment, and Turnover Intention: Evidence from the Gambling Industry in Macau. Business and Management Studies, 2(1), 104-110. doi:http://dx.doi.org/10.11114/bms.v2i1.1280 
INTERNATIONAL JOURNAL OF ACADEMIC RESEARCH IN BUSINESS AND SOCIAL SCIENCES

Vol. 8, No. 7, July 2018, E-ISSN: 2222-6990 @ 2018 HRMARS

Xie, D. (2005), "Exploring organizational learning culture, job satisfaction, motivation to learn, organizational commitment, and internal service quality in a sport organization", available at: http://etd.ohiolink.edu/send-pdf.cgi/Xie\%20Di.pdf?acc_num\%1/40su1124138607 $\quad 23$ September 2009). 